International Journal of Zoological Investigations

Contents available at Journals Home Page: www.ijzi.net

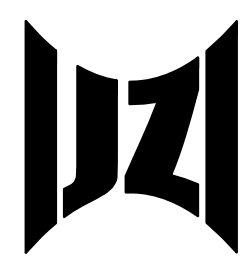

ISSN: 2454-3055

\title{
Thermal-Aroma-Organic-Carbon-Fusion Therapy: An Open Air Conventional Method for Clearance of Nasal Air Passage, Trachea, Lungs and Immunity Boosting Against Influenza Virus
}

\author{
Upadhyay R. K.
}

Department of Zoology, Deen Dayal Upadhyaya Gorakhpur University. Gorakhpur, 273009, India

Received: $13^{\text {th }}$ April, 2020

Accepted: 22nd April, 2020

Published online: $25^{\text {th }}$ April, 2020

https://doi.org/10.33745/ijzi.2020.v06i01.007

\begin{abstract}
Present research article explains a composite thermal-aroma-organic-carbon fusion therapy to instantly fight against flu virus/human corona virus. The key concept behind this therapy is to kill invisible virus/enemy by using highly active untraceable /unrecognizable carbon and drug molecules. However, for making a cumulative defense against flu virus different methods were used. High energy thermal waves (light spectrum/radiation) generated by mustard oil lamp will denature flu virus in high temperature air zone created above flame and its surroundings. Further, carbon nano-particle colloids hit virus RNA particle and due to Tyndall effect super collusion take place between them in hot air. Thus, thermal waves assist carbon colloids and volatile essential oil components infuse together with virus in air and neutralize its activity. In addition, inhalation of this warm air will clear passageways, trachea and lungs more efficiently. It will not only lower down adherence/ attachment of flu virus to nasal and bronchus epithelial lining but also reduce virus load. Further, organic carbon present in bhasma, admixture with honey and alum forms a thick sticky colloidal mass that over-layer upon gut mucosa after oral use. It could trap the virus and inhibit binding of virus spike protein with ACE- 2 receptors found on human cells. In addition to it, regular use of herbal syrup prepared from natural constituents will stop formation of mucus precipitated coat and dissolve it by quick action. Proper use of this composite therapy will save patients from sneezing, running nose, dry cough, fluid filling and cytokine burst in lungs and prohibit virus infiltration in liver, kidney and other tissues.. It will cut down morbidity and save patient from sepsis that occurs in vital organs. Regular use of organic syrup will generate primary humoral immune response in patient. It will provide longevity to patient beyond 14 days (up to 28 days) until long term immune defense is being made in the patient body and infection disappear completely. This therapy will cut down/ reduce requirement of ventilator but it will need development of technology. For its safe use human trials are to be done by some responsible agency by permission of government.
\end{abstract}

Keywords: Corona virus, Spike protein, Carbon particle, Essential oils, Thermal denaturation, Alum

Citation: Upadhyay R. K.: Thermal-Aroma-Organic-Carbon-Fusion therapy: An open air conventional method for clearance of nasal air passage, trachea, lungs and immunity boosting against Influenza Virus. Intern. J. Zool. Invest. 6 (1): 71-93, 2020. https://doi.org/10.33745/ijzi.2020.v06i01.007

Editorial: The Editorial members of the journal are not responsible in anyway for the opinion and methods suggested by the author. 


\section{Introduction}

Viruses show unpredictable recurring outbreaks that lead to devastating mortality, and great economic losses. Covid-19 viral infections alone posed a significant global health challenge in present time. It has affected millions of people worldwide, and showing its high aggression in Europe and America after making thousands of fatalities made in China. This is very unfortunate that correct data from China is not still available about infected people, morbid numbers and deaths. China has even not truly reported its epidemiology and its emergence till last of November 2019. Virus infection in United States, England, France, Spain, and Italy is on peak. India is also on war path and fighting against the virus. In November 2002 atypical pneumonia was reported in Guangdong province of China. Within next few weeks this disease was evoked and spread in seven other provinces of China. In 2003 it was named as SARS (Severe Acute Respiratory Syndrome) with 8096 cases and 774 deaths were reported. Its etiologic agent was identified as a corona virus, because of spike protein looks like a shape of crown. This human corona virus showed a mild form of common cold with very few deaths, became silent after one and half year, again and suddenly evoked in November 2019 possibly a mutated form of corona virus with high infectivity and death rate. As nature of viruses, this corona virus assumed mutation by its own, but it cannot be denied a rapid lethal mutation is possibly done in some defense laboratory. Now this is much speculated this virus might have spilled out from there. This is un-imaginable that Covid-19 has been spread worldwide within 120 days and gripped whole world in its fatal clutches. Virus has been imposing serious public health threat and making heavy economic losses to human society mainly to world economy.

Essential oils as strong anti-viral agents:

Essential oils are proved as strong antimicrobial agents. They showed preventive effect against different viruses, but they cannot stop virus entry way into host body (Piątkowska and Rusiecka-Ziółkowska,_2016). Ginger essential oil (caprine) also shows strong antivirus activity against alpha herpes virus-1 and human herpes simplex viruses (HSV-1 and -2) (Camero et al., 2019). Eugenin, a compound isolated from Syzygium aromaticum and from Geum japonicum, Clove (Syzygium aromaticum) also showed antiviral activity. Similar activity is reported in Mentha piperita (Rosato et al., 2018) and Ocimum tenuiflorum (synonym Ocimum sanctum). There are series of essential oils which have been tested against various disease pathogens. Among few of them is star anise oil, which proved antiviral when, assayed by plaque reduction method against virus suspension of HSV-1. Tea tree oil showed strong anti-inflammatory and antiseptic properties. Star anise essential oil contains trans-anethole a phenylpropanoid and sesquiterpenes and show antiviral activity against herpes simplex virus type 1 (HSV-1) in vitro (Astani et al., 2011). Similar anti-viral activity is also reported in Melaleuca armillaris (Schnitzler et al., 2001) and Oregano essential oil causes dissolution of the HSV envelope at a very mild dose in vitro assays (Siddiqui et al., 1996). De Logu et al. (2000) did inactivation of herpes viruses by using Santolina insularis essential oil. Sesquiterpenes, for example triptofordin C-2 
and sesquiterpene coumarins were found active against cytomegalovirus and inhibit its invasion (Hayashi et al., 1996). A clove essential oil component eugenol phenylpropane delayed the development of herpesvirus-induced keratitis in the mouse model (Benencia and Courrges, 2000). Isoborneol, a monoterpene reported in several plant essential oils, display virucidal activity against HSV-1 and specifically inhibit glycosylation of viral proteins (Armaka et al., 1999) and target SARS (Severe Acute Respiratory Syndrome), coronavirus (Wen, et al., 2007) and rhinovirus (Rollinger, et al., 2008). Different essential oil blends are also used against viral and fungal infection (Brocht et al., 2017).

\section{Thermal denaturation of corona virus particle:}

Thermal denaturation of virus could be possible by using either alkali or by using 1.5 M NaCl (Wallace and Franklin, 1967). This salt precipitated virus do not found resistant to digestion by ribonuclease. The RNA is also denatured in the salted fluid and its reannealing is not possible if thermal heat is provided above 45 degree temperature (Rice and Doty, 1957). Similar thermal denaturation of influenza virus was studied by Epand and Epand (2002). Conformational changes in the hemagglutinin of influenza virus are also perceived by heat-induced fusion of virus with liposomes (Ruigrok et al., 1986). Influenza A virus loses its stability at low $\mathrm{pH}$ and thermal inactivation to elevated temperature (Scholtissek, 1985; De Flora and Badolati, 1973).

Use of carbon nano-particles and its colloids:

Coronavirus virions are spherical pleomorphic particles with diameters of approximately $125 \mathrm{~nm}$. These display bulbous surface projections (Estola, 1970). Diameter of the envelope in this virus is $\sim 80 \mathrm{~nm}(0.08$ $\mu \mathrm{m})$. The most prominent feature of coronaviruses is the club-shape spike projections coming out from the surface of the virion. These spikes are $\sim 20 \mathrm{~nm}(0.02 \mu \mathrm{m})$ long. Coronavirinae having the largest identified RNA genomes, containing approximately 30 kilobase $(\mathrm{kb})$ genomes. Within the envelope of the virion is the nucleocapsid. Coronaviruses have helically symmetrical nucleocapsids, which is uncommon among positive-sense RNA viruses. Colloidal carbon produced in the form of a hot smoke of small globular particles (typically $\sim 30 \mathrm{~nm}$ ), which on cooling undergo aggregation to give branched chain-like structures. These are composed of very small particles, with BET-areas $\sim 100 \mathrm{~m}^{2} \mathrm{~g}^{-1}$ It is also clear from research studies that nanoscale carbon is used for drug-encapsulation (DECON). This carbon-encapsulation of drug enhances its delivery to target organ (Tejabhiram Yadavalli et al., 2019). Carbon Dots also showed antiviral functions against Noroviruses (Xiuli et al., 2017). These carbon nano- particles are also used in drug encapsulation for combating emerging viral (NIPAH virus) infection (Kerry et al., 2019).

Use of alum to prepare an immunogen:

White alum is used as adjuvant to prepare immunogen for development of vaccines. It includes ammonium salts precipitated under basic conditions. Aluminum works as a carrier of antigen, as it binds and absorbs them and easily does their retention after injection into the host body (Mirjam Kool et al., 2012). Addition of alum influence vaccine immunogenicity more especially antibody response but it does not enhance CD-8 cell responses (Harm HogenEsch et al., 2018). 
This is a mild irritant and show local inflammatory responses after use. With increasing threats of emerging microbes, originating from natural or man-made sources, that pose significant health concerns at the population scale, the potential use of alum works as 'first-aid' vaccine. Alum is an oldest adjuvant which was used for preparation of vaccines mainly for transportation of bound antigens in animal model (Mirjam Kool et al., 2011), Use of alum generates $\mathrm{T}$ helper 1 responses (Lindblad, 2004; Hem and HogenEsch et al., 2007). As equivalent to Freund's complete adjuvant, it also continuously induces $\mathrm{T}$ helper 2 cytokine production in interleukin-4-deficient mice (Brewer et al., 1996). Potash alum is also used for surface killing of hepatitis virus (Yasir Waheed et al., 2011). Use of alum increases phagocyte activation, caspase-1 conversion and IL-1 $\beta$ production in antigen-presenting cells. It form inflammasome/activated caspase-1 (Davis et al., 2011) that mediate several forms of cell death and does conversion of immature precursors of inflammatory cytokines to their active forms i.e. interleukin-1 $\beta$ (IL-1 $\beta$ ), IL-18 and IL-33 (Sutterwala et al., 2014). Production of these cytokines enhances $\mathrm{Ca}^{2+}$ influx, $\mathrm{K}^{+}$efflux and generates mitochondria-originated reactive oxygen species (Li et al., 2007).

\section{Use of anti-virus natural plant products:}

Various plant parts such as leaves, bark, flower, flower buds, spices, condiments were used from many plants i.e. Azwain or Ajwain, Holy Tulsi, Pepper, Giloy or gaduchi, Ghrit Kumari, Laung (clove), Chirayata or Swertia, Ginger, Kareel fruit, Curry tree leaves, Dalchini, Satawari, Jaifal or nutmeg, Haldi (turmeric), Kansh root and Kesar for preparation of cough syrup that can finish congestion, sore throat, watery nose and sneezing, infection in upper respiratory tract and cut down swelling of lungs. More specifically these plant products have been selected on the basis of their active ingredients tested curative and protective against flu viruses. Most of them possess antiinflammatory, antiseptic, anti- bronchitis, astringent, laxative, and kidney and hepatoprotective effects. These relieve cold and dry cough, can fight against gastro-intestinal disorders, and boosting the immune system. Shatavari successfully used to treat gastric ulcer (Table 1). Most of the natural plant products tested have shown anti-virus efficacy in vitro (Vlietinck et al., 2006).

The main aim behind designing this method is clearance of nasal air passageways, trachea mainly upper respiratory tract. It also stop nasal flow, sneezing and congestion. Various plant origin ingredients used in preparation of a syrup provide relief in dry cough formed in bronchus. Further, various volatile components of essential oil and aired organic carbon and thermal heat inhaled regularly for 15-20 minutes will increase the tidal volume or inspiration capacity of patient or normal person. It will assist in normalization or restoration of vital lung function/capacity, restoration of cellular respiration and mitochondrial function within an hrs time. More suggesting point is to stop extracellular ATP hydrolysis in patient's body by making an overall clearance of virus from respiratory air passageways, upper respiratory tract, trachea, gut mucosa, lungs, and stop its infiltration in lymph nodes kidney and liver. Inhalation of aroma can also stop expression of virus in brain cells. Various concoctions and syrup prepared by using various plant parts will not only remove dry 
Table 1: Ingredients used in to prepare a hot syrup preparation for controlling of dry cough, congestion, bronchial swelling, and breathing problems

\begin{tabular}{|c|c|c|c|c|c|c|}
\hline No & Name of plant & Scientific name & Family & Chemical constituents & $\begin{array}{l}\text { Quantity } \\
\text { and part } \\
\text { used }\end{array}$ & Effectiveness \\
\hline 1 & $\begin{array}{l}\text { Azwain or } \\
\text { Ajwain }\end{array}$ & $\begin{array}{l}\text { Trachyspermum } \\
\text { ammi }\end{array}$ & Apiaceae & $\begin{array}{l}\text { Thymol, gamma-terpinene, p- } \\
\text { cymene, gamma terpinene, } \\
\text { beta-pinene. cymene }\end{array}$ & $\begin{array}{c}\text { Seed } \\
2.132 \% \\
\mathrm{w} / \mathrm{v}\end{array}$ & $\begin{array}{l}\text { Cough, congestion, seeds are rich in fiber, } \\
\text { minerals, vitamins and antioxidants, thymol in } \\
\text { ajwain seeds acts as a strong fungicide and } \\
\text { germicide, anti-arthritis, and relieve from } \\
\text { muscular-joint pain. }\end{array}$ \\
\hline 2 & Holy Tulsi & $\begin{array}{c}\text { Holy } \\
\text { basil (Ocimum } \\
\text { tenuiflorum }\end{array}$ & Lamiaceae & $\begin{array}{l}\text { Estragole,carvacrol, rosmarinic } \\
\text { acid, oleanolic acid }\end{array}$ & $\begin{array}{l}\text { Leaves } \\
2.15 \% \\
\mathrm{w} / \mathrm{v}\end{array}$ & $\begin{array}{c}\text { Leaves contain } 0.7 \% \text { volatile oil comprising } \\
\text { about } 71 \% \text { eugenol and } 20 \% \text { methyl eugenol } \\
\text { decrease pain and swelling, improve survival rate, } \\
\text { as an antioxidant.anticancer }\end{array}$ \\
\hline 3 & Pepper & $\begin{array}{c}\text { Long } \\
\text { pepper (Piper } \\
\text { longum) }\end{array}$ & Piperaceae & $\begin{array}{l}1 \% \text { volatile oil, } 1.25 \% \text { piperine } \\
\text { and } 40 \% \text { starch }\end{array}$ & $\begin{array}{c}\begin{array}{c}\text { Minuscule } \\
\text { fruits }\end{array} \\
0.15 \% \\
\text { w/v }\end{array}$ & $\begin{array}{l}\text { Improve appetite and digestion, as well as treat } \\
\text { stomachache, heartburn, indigestion, intestinal } \\
\text { gas, diarrhea, and cholera. It is also used for } \\
\text { lung problems including asthma, bronchitis, and } \\
\text { cough }\end{array}$ \\
\hline 4 & $\begin{array}{l}\text { Giloy or } \\
\text { gaduchi }\end{array}$ & $\begin{array}{l}\text { Tinospora } \\
\text { cordifoli }\end{array}$ & Menispermaceae & $\begin{array}{l}\text { Alkaloids, diterpenoid lactones, } \\
\text { glycosides, steroids, } \\
\text { sesquiterpenoid, phenolics, } \\
\text { aliphatic compounds and } \\
\text { polysaccharides. }\end{array}$ & $\begin{array}{c}\text { Fleshy stem } \\
0.35 \% \\
\text { w/v }\end{array}$ & $\begin{array}{l}\text { Contains calcium phosphorus and other } \\
\text { minerals, strong anti-dry cough and enhance } \\
\text { body immunity. }\end{array}$ \\
\hline 5 & Ghrit Kumari & Aloe Vera & Asphodelaceae & $\begin{array}{l}\text { Anthraquinones, enzymes, } \\
\text { minerals, vitamins, lignins, } \\
\text { monosaccharide, } \\
\text { polysaccharides, salicylic acid, } \\
\text { saponins, and sterols }\end{array}$ & $\begin{array}{c}\begin{array}{c}\text { Fleshy } \\
\text { leaves }\end{array} \\
0.23 \% \\
\text { w/v }\end{array}$ & $\begin{array}{l}\text { salicylic acid an aspirin-like compound with anti } \\
\text {-inflammatory, analgesic, and anti-bacterial } \\
\text { properties. inflammation }\end{array}$ \\
\hline 6 & Black pepper & $\begin{array}{c}\text { Black } \\
\text { pepper (Piper }\end{array}$ & Piperaceae & $\begin{array}{c}\text { Piperine, } \\
\text { pinene,ocimene, Vitamin C, }\end{array}$ & $\begin{array}{l}\text { Fruit, single } \\
\text { seed, like all }\end{array}$ & $\begin{array}{l}\text { Anti-oxidants help to remove harmful free } \\
\text { radicals and protect the body from cancers and } \\
\text { diseases, depression. It stimulates the brain, }\end{array}$ \\
\hline
\end{tabular}




\begin{tabular}{|c|c|c|c|c|c|c|}
\hline & & nigrum & & Vitamin A, flavonoids, carotenes & $\begin{array}{c}\text { drupes } \\
0.125 \% \\
\text { w/v }\end{array}$ & $\begin{array}{l}\text { and helps it to function properly by making it } \\
\text { more active, black pepper eases digestion and } \\
\text { stimulates the stomach, which then secretes } \\
\text { more hydrochloric acid that helps to digest } \\
\text { proteins in food, relieves cold and cough }\end{array}$ \\
\hline 7 & Laung (clove) & $\begin{array}{l}\text {, Syzygium } \\
\text { aromaticum. }\end{array}$ & Myrtaceae & $\begin{array}{c}\text { Acetyleugenol, beta- } \\
\text { caryophyllene, vanillin, crategol } \\
\text { ic acid, tannins such } \\
\text { as bicornin, gallotannic } \\
\text { acid, methyl } \\
\text { salicylate (painkiller), } \\
\text { eugenin, kaempferol, rhamnetin } \\
\text {, and eugenitin, triterpenoids }\end{array}$ & $\begin{array}{c}\text { Long calyx } \\
0.82 \% \\
\text { w/v }\end{array}$ & $\begin{array}{l}\text { Anticancer, hepatoprotective, immunity } \\
\text { booster, antiseptic, anti-fungal, antibacterial, } \\
\text { antioxidant, analgesic, anti-inflammatory }\end{array}$ \\
\hline 8 & $\begin{array}{c}\text { Chirayata or } \\
\text { Swertia }\end{array}$ & $\begin{array}{l}\text { Gentiana } \\
\text { chirayita }\end{array}$ & Gentianaceae & $\begin{array}{c}\text { Phelic acid, amarogentin, } \\
\text { chiratin, chiratogenin, } \\
\text { enicoflavine, gentianine, } \\
\text { swertianin and swerchirin, } \\
\text { resins, gum, carbonates and } \\
\text { phosphates of potash lime and } \\
\text { magnesia ash }\end{array}$ & $\begin{array}{c}\begin{array}{c}\text { Spike and } \\
\text { stem }\end{array} \\
0.12 \% \\
\text { w/v }\end{array}$ & $\begin{array}{l}\text { Remove general weakness, relieve kapha } \\
\text { and pitta doshas. } \\
\text { anti-inflammatory and reduces } \\
\text { inflammation, anti-asthmatic and expectorant } \\
\text { properties which can effectively treat asthma, } \\
\text { tonic for liver, ends, fever }\end{array}$ \\
\hline 9 & Ginger & $\begin{array}{c}\text { Zingiber } \\
\text { officinale Rosc }\end{array}$ & Zingiberaceae & $\begin{array}{c}\text { Zingerone, shogaols, } \\
\text { and gingerols with [6]-gingerol } \\
(1-[4 \text { '-hydroxy-3'- } \\
\text { methoxyphenyl]-5-hydroxy-3- } \\
\text { decanone), enzyme zingibain is } \\
\text { a cysteine protease } \alpha \text { - } \\
\text { zingiberene, ar-curcumene, } \beta \text { - } \\
\text { bisabolene, } \beta \text { - } \\
\text { sesquiphellandrene, zingiberol } \\
\text { and zingiberenol, }\end{array}$ & $\begin{array}{c}\text { Rhizome } \\
1.2 \% \\
\mathrm{w} / \mathrm{v}\end{array}$ & $\begin{array}{c}\text { Treating nausea, dysentery, heartburn, } \\
\text { flatulence, and diarrhea, loss of appetite, } \\
\text { infections, cough, and bronchitis. 6-gingerol and } \\
\text { 6-shogaol exert anticancer activities against GI } \\
\text { cancer. }\end{array}$ \\
\hline 10 & Kareel fruit & Capparis decidua & Capparaceae & $\begin{array}{l}\text { Stachydrine, } \beta \text {-carotene, Rutin, } \\
\text { Isothiocynate, Glucosides, } \\
\text { Hydrocarbons and Fatty acids. }\end{array}$ & $\begin{array}{l}\text { Fruit } \\
1.2 \% \\
\mathrm{w} / \mathrm{v}\end{array}$ & $\begin{array}{l}\text { Used to cure toothache, arthritis, asthma, cough, } \\
\text { inflammation, intermittent fevers, malaria, } \\
\text { rheumatism, and swelling. It is also believed to } \\
\text { possess laxative, astringent and } \\
\text { hepatoprotective effect vermifuge propertie }\end{array}$ \\
\hline 11 & $\begin{array}{c}\text { Curry tree } \\
\text { leaves }\end{array}$ & Murraya koenigii & Rutaceae & $\begin{array}{l}\text { Cinnamaldehyde, and numerous } \\
\text { carbazole alkaloids, including } \\
\text { mahanimbine, girinimbine, and }\end{array}$ & $\begin{array}{c}\text { Leaves } \\
0.67 \% \mathrm{w} / \mathrm{v}\end{array}$ & $\begin{array}{l}\text { Diarrhea, gastro-intestinal disorders, protect } \\
\text { from air borne pathogens, leaf powder } \\
\text { improves oral health and relieve kidney }\end{array}$ \\
\hline
\end{tabular}




\begin{tabular}{|c|c|c|c|c|c|c|}
\hline & & & & mahanine. & & problems. \\
\hline 12 & Dalchini & $\begin{array}{c}\text { Cinnamon } \\
\text { (Cinnamomum } \\
\text { zeylanicum, and } \\
\text { Cinnamon cassia), }\end{array}$ & Lauraceae & $\begin{array}{l}\text { Vital oils and other derivatives, } \\
\text { such as cinnamaldehyde, } \\
\text { cinnamic acid, and methyl } \\
\text { cinnamate, eugenol, cinnamyl } \\
\text { acetate. }\end{array}$ & $\begin{array}{c}\text { Dried bark } \\
0.83 \% \\
\mathrm{w} / \mathrm{v}\end{array}$ & $\begin{array}{l}\text { Antioxidant, anti-inflammatory, antidiabetic, } \\
\text { antimicrobial, anticancer, lipid-lowering, and } \\
\text { cardiovascular-disease-lowering compound, } \\
\text { cinnamon has also been reported to have } \\
\text { activities against neurological disorders }\end{array}$ \\
\hline 13 & Satawari & $\begin{array}{l}\text { Asparagus } \\
\text { racemosus }\end{array}$ & Asparagaceae & $\begin{array}{l}\text { Steroidal saponins. Isoflavones, } \\
\text { asparagamine, racemosol, } \\
\text { polysaccharides, mucilage, } \\
\text { vitamins A, B1, B2, C, E, Mg, P, } \\
\mathrm{Ca}, \mathrm{Fe} \text {, and folic acid present in } \\
\text { roots. }\end{array}$ & $\begin{array}{c}\text { Leaves } \\
0.37 \% \mathrm{w} / \mathrm{v}\end{array}$ & $\begin{array}{l}\text { balance Vata and Pitta, shatavari may help treat } \\
\text { gastric ulcers, a condition that occurs when the } \\
\text { protective lining of the stomach breaks down } \\
\text { and fails to fight off irritating acids, Bronchitis, } \\
\text { pain relief, small pine-needle-like phylloclades } \\
\text { dried roots }\end{array}$ \\
\hline 14 & $\begin{array}{l}\text { Jaifal or } \\
\text { nutmeg }\end{array}$ & $\begin{array}{c}\text { Myristica } \\
\text { fragrans Houtt }\end{array}$ & Myristicaceae & $\begin{array}{l}\text { Alpha-pinene, camphene, beta- } \\
\text { pinene, sabinene, myrcene, } \alpha \text { - } \\
\text { phellandrene, } \alpha \text {-terpinene, } \\
\text { limonene, 1,8-cineole, } y- \\
\text { terpinene, linalool, terpinen-4- } \\
\text { ol, safrole, methyl eugenol and } \\
\text { myristicin. }\end{array}$ & $\begin{array}{l}\text { Nut } \\
0.125 \% \\
\text { w/v }\end{array}$ & $\begin{array}{l}\text { Anti-cough, asthma, diarrhea, antioxidant anti- } \\
\text { diarrheal, stimulant, carminative, astringent, } \\
\text { aphrodisiac and abortifacient (causing } \\
\text { abortion) properties. It is used for treating colic, } \\
\text { indigestion, loose motion, gas, nausea, } \\
\text { rheumatism, etc. }\end{array}$ \\
\hline 15 & $\begin{array}{c}\text { Haldi } \\
\text { (turmeric) }\end{array}$ & Curcuma longa & Zingiberaceae, & $\begin{array}{l}\text { 3-6\% polyphenolic compounds, } \\
\text { collectively known as } \\
\text { curcuminoids, curcumin, } \\
\text { demethoxycurcumin and } \\
\text { bisdemethoxycurcumin. }\end{array}$ & $\begin{array}{c}\text { Roots } \\
0.92 \% \mathrm{w} / \mathrm{v}\end{array}$ & $\begin{array}{l}\text { Used in indigestion (dyspepsia), abdominal } \\
\text { pain, hemorrhage, diarrhea, flatulence, abdomin } \\
\text { al bloating, loss of appetite, jaundice, hepatitis, } \\
\text { and liver and gall bladder diseases, superoxide } \\
\text { anion scavenging activity }\end{array}$ \\
\hline 16 & Kansh & $\begin{array}{c}\text { Saccharum } \\
\text { spontaneum }\end{array}$ & Poaceae & $\begin{array}{l}\text { alkaloids, carbohydrates and } \\
\text { glycosides, } \\
\text { phenolic compounds, saponins, } \\
\text { tannins, protein and amino } \\
\text { acids, coumarins \& flavonoids } \\
\text { as active constituents }\end{array}$ & $\begin{array}{c}\text { Rhizomatou } \\
\text { s roots } \\
0.42 \% \\
\mathrm{w} / \mathrm{v}\end{array}$ & $\begin{array}{l}\text { Used to treat Kidney stone, dyspepsia, piles, } \\
\text { sexual weakness, gynecological disorders, } \\
\text { respiratory problems, burning sensation }\end{array}$ \\
\hline 17 & Kesar & Crocus sativus & & $\begin{array}{l}\text { Dried flower } \\
\text { act as antioxidants - molecules } \\
\text { that protect your cells against } \\
\text { free radicals and oxidative } \\
\text { stress, protect brain cells }\end{array}$ & $\begin{array}{l}\text { Root } \\
0.02 \%\end{array}$ & $\begin{array}{l}\text { Crocin, } \alpha \text {-crocin, carotenoids that include } \\
\text { lycopene, zeaxanthine, and both alpha- and } \\
\text { beta- carotenes, crocetin, and picrocrocin. } \\
\text { Picrocrocin, safranal, ncluding carotenoids, } \\
\text { including zeaxanthin, lycopene, and various } \alpha \text { - }\end{array}$ \\
\hline
\end{tabular}




\begin{tabular}{|c|c|c|c|c|c|c|}
\hline & & & & $\begin{array}{c}\text { against progressive } \\
\text { damage, improve inflammation, } \\
\text { antidepressant activity }\end{array}$ & $\mathrm{w} / \mathrm{v}$ & and $\beta$-carotenes.[37] \\
\hline 18 & Deshi Genda & Tagetus erecta & Asteraceae & $\begin{array}{l}\text { Contains essential oil limonene, } \\
\text { ocimene, linalool, linalyl acetate, } \\
\text { tagetone and n-nonyl aldehyde }\end{array}$ & $\begin{array}{l}\text { Petals only } \\
\qquad .2 \%\end{array}$ & $\begin{array}{l}\text { used in digestive ailments, such as stomach } \\
\text { pain, as well as diarrhea, colic, liver } \\
\text { problems, bile, vomiting, } \\
\text { and indigestion. respiratory diseases such as } \\
\text { colds, flu, bronchitis and nasal congestion }\end{array}$ \\
\hline 19 & $\begin{array}{c}\text { Spear Mint or } \\
\text { Pudina }\end{array}$ & $\begin{array}{l}\text { Mentha Arvensis } \\
\text { Linn }\end{array}$ & Lamiaceae & $\begin{array}{c}\text { Menthol (27-51\%), menthone } \\
(13-32 \%), \text { isomenthone }(2- \\
10 \%), 1,8 \text {-cineole }(5-14 \%), \\
\text { methyl acetate }(2-4 \%), \\
\text { methofuran }(2- \\
12 \%) \text {, limonene }(0.5-6 \%), \\
\text { pinenes }(1.5-4 \%) \text {, germacrene } \\
(2.1-4.3 \%) \text { and pulegone }(0.1- \\
1 \%)\end{array}$ & $\begin{array}{c}\text { Leaves } \\
\\
0.231 \% \\
\text { w/v }\end{array}$ & $\begin{array}{l}\text { Queasy stomachs, calming stress and anxiety, } \\
\text { and promoting restful sleep, calming the } \\
\text { digestive tract and alleviating indigestion, gas, } \\
\text { and cramps.. }\end{array}$ \\
\hline 20 & White alum & $\begin{array}{l}\text { hydrated double } \\
\text { sulfate salt of } \\
\text { aluminum }\end{array}$ & potassium alum, & formula $\mathrm{KAl}\left(\mathrm{SO}_{4}\right)_{2} \cdot 12 \mathrm{H}_{2} \mathrm{O}$ & $0.3 \%$ & $\begin{array}{c}\text { Aluminium hydroxide gel used as a vaccine } \\
\text { adjuvant or enhances the immune response, } \\
\text { enhances the immune response, enhances the } \\
\text { immune response }\end{array}$ \\
\hline
\end{tabular}

*All ingredients used were in per cent $\mathrm{w} / \mathrm{v}$ and are wet in nature. A fresh material is used always.

*Few ingredients were dry hence powdered, wet material was meshed and processed to make thick slurry, both types were dissolved and mixed in $100 \mathrm{X} 10 \mathrm{ml}(1000 \mathrm{ml}$ for 10 syrup bottles of $100 \mathrm{~mL}$ each ingredients used in same multiplying ratio) of water and boiled for 20 - 30 minutes till half of the volume is evaporated. To this 0.3 gm X 10 bottles (3gms for $1 \mathrm{~L}$ ) white alum was added, again it was boiled and a $2 \mathrm{~g}$ fresh cane jiggery was added for thickness and conditioning of all materials for their final activity. Store this home prepared syrup in clean, cool and dry place in bottle. 
cough but its four time use will lower down patient fever below $100.4{ }^{\circ} \mathrm{F}$, and provide relief from fever without phlegm. It will boost both innate and cell mediated and humoral immune functions of patient's body, and save mucosal epithelial cells in lungs and gastrointestinal tract. Use of rose water will disinfect patient eyes. Both short term and long term control methods have been designed for use.

Strategic design, use and application of composite therapy:

(1) First method: Clearance of air passageways by inhalation of hot air:

Use hot water concoction for gargles with $2 \%$ table salt water mixed with $0.1 \%$ turmeric, azwain $1 \%$, mint leaves $(1.0 \mathrm{~g})$, citrus lemon leaves or peal of orange (2.0 g) and 5-6 drops of clove bud essential oil. Use same mixture for hot air distillate steam inhalation (bafara) for 30 minutes at least twice a day. Take sunbath in open air for 15-20 minutes a day by making social distancing.

(2) Second method: Disinfection of eyes or killing of virus in eyes:

Take $100 \mathrm{ml}$ of rose water (with no preservative) and add to it $100 \mathrm{mg}$ of white alum powder. Use five to six times two drops each time.

\section{(3) Third method:}

Take $10 \mathrm{~g}$ of deshi cow ghee and add $100 \mathrm{mg}$ of camphor, warm both in steel utensil, till both mixes well, use it for massage over chest, back, shoulders, knee and sole of both foot.

(4) Fourth method: Immunity boosting, restoration of vital functions and wound healing:

(i) Preparation one:
Take $10 \mathrm{~g}$ fresh leaves of curry patta, $5.0 \mathrm{gm}$ leaf of citrus lemon and 5.0 gm of chirayta spikes with stem. Chop all them in to small pieces with a knife, put them in $200 \mathrm{ml}$ of water in a fry pan on a gas burner, add $1 \mathrm{~g}$ of black salt and $1 \mathrm{~g}$ of black pepper in it, boil it till $100 \mathrm{ml}$ of it remains in the pan (Fig. 1). Use $10 \mathrm{ml}$ of it twice a day as with equal amount of lukewarm water.

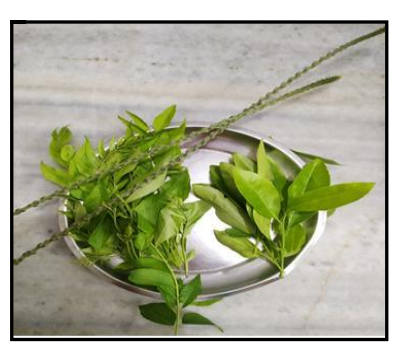

(a)

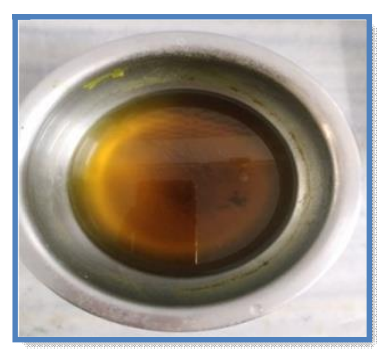

(b)
Fig. 1: (a) Fresh leaves of Chirayata, curi patta tree, and lemon (b) Hot extract/concoction of leaves

\section{(2) Preparation two:}

Few ingredients (mentioned in table 1) were powdered, wet material was meshed and processed to make thick slurry, both were dissolved and mixed in $100 \mathrm{X} 10 \mathrm{ml}$ (for 10 syrup bottles of $100 \mathrm{ml}$ each; ingredients multiply in same ratio) of water and boiled for 20-30 minutes till half of the volume is evaporated. To this $0.3 \mathrm{~g} \mathrm{X10}$ white alum was added, again it was boiled and $2 \mathrm{~g}$ fresh cane jiggery (for $100 \mathrm{ml}$ ) is added for thickness and conditioning of all plant materials for their final activity. Store this home prepared syrup in clean, cool and dry place in bottle. All ingredients used were in per cent $\mathrm{w} / \mathrm{v}$ and are wet in nature. A fresh material is used always.

(5) Fifth method: Thermal aroma carbon infusion and its inhalation:

It is very clear from clinical researches that inhalation of essential oil aroma is the most 


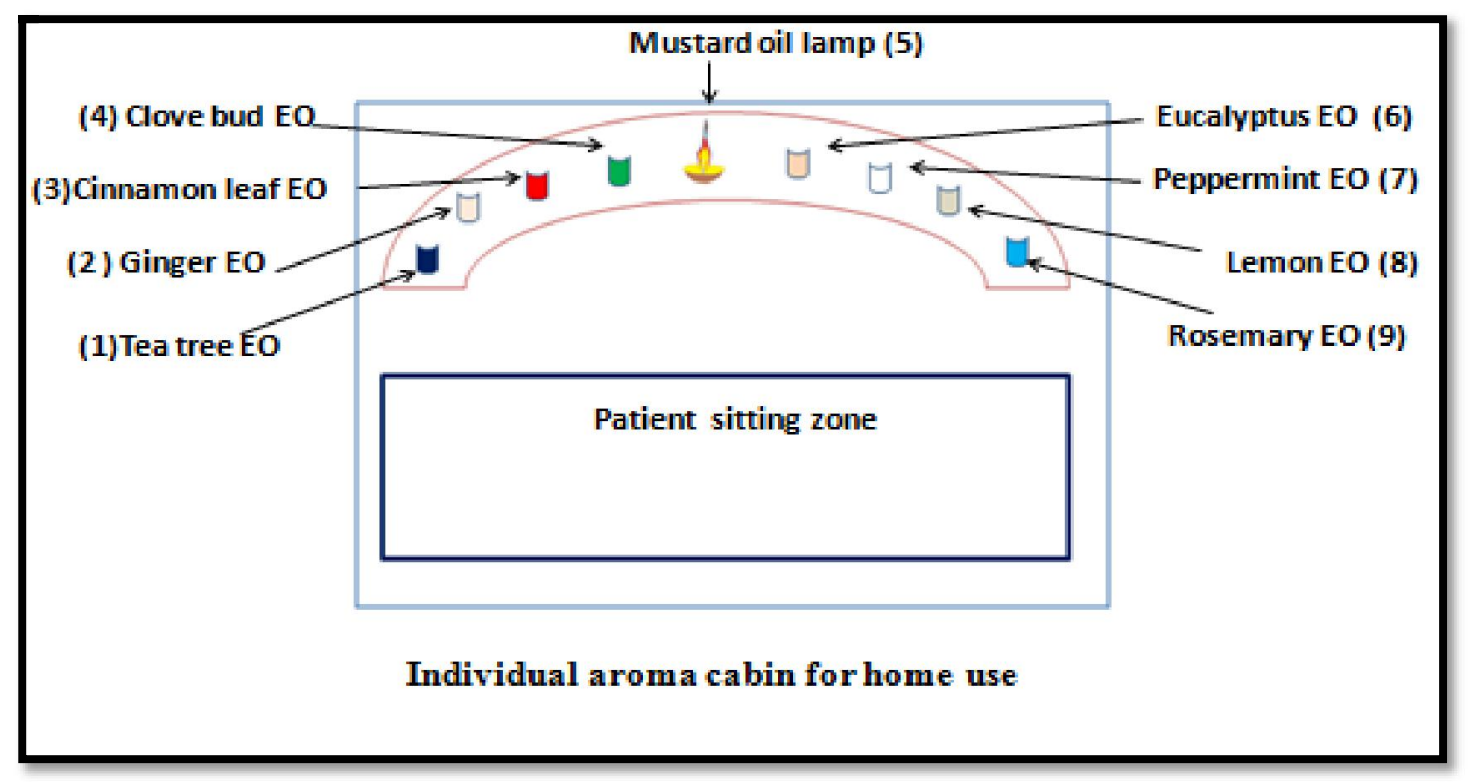

Fig. 2: home use thermal aroma chamber 1-4 and 6-9 number of different essential oils. In central place mustard oil Diya (Lamp) filling with edible oil to be lighten at no 5. Distance between central lamp and patient should be 1 feet. Keep room door open and sit in first aroma and thermal circle. For rest of the information see method mentioned in main text.

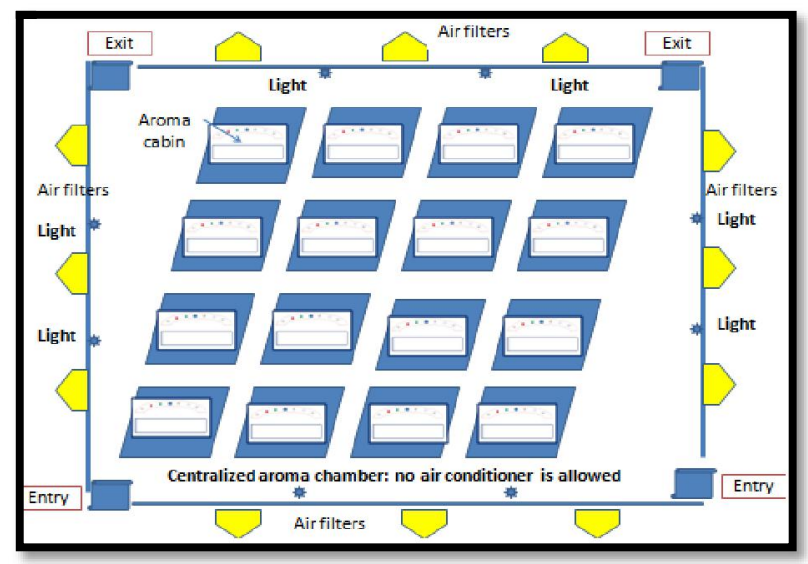

Fig. 3: Large scale use of thermal aroma chamber 1-4 and 6-9 number of different essential oils. In central place mustard oil (edible oil) diya is to be lighten at no 5. Distance between central lamp and patient should be 1 feet. Keep room door open and sit in first aroma and thermal circle. For rest of the information see method mentioned in main text. Within 15-30 minutes time 16 patients can be treated easily.

beneficial to keep away flu viruses. Before using this therapy use coconut oil for massage it on both sides of chest, neck and frontal and temporal sides of head. Before 30 minutes of this therapy, provide one glass of lukewarm water with 5 drops of citrus lemon juice to stop excess dehydration during aroma therapy from patient/quarantine patient. Two separate aroma-thermal chambers will be required to treat uninfected and infected persons in aroma thermal cabin. Its design is given in Figure 2 for individual home use. For large scale use and to treat 16 persons at a time design is mentioned in Figure 3. Inhalation time 9-10 minutes for normal uninfected and 15-20 minutes for infected cases. Essential oils must be strictly arranged according to number used in figure, keep 
them over a bench and allow their controlled release (Table 2). For better exposure person should sit inside inner zone of 1.44 square feet area. Before using this therapy patients are advised to have a small topical application applying few drops of oils on to their skin to test its toxic effect. If anyone find affected with severe or worsening symptoms of flu should seek medical help and should not use this method.

Present method has been tested successfully in limited trials and resources. Large scale human trials are highly needful to determine both dosage and and efficacy of method by some government agency/institution. Hence, for confirmation of effectiveness of method, formulations used and their side effects are only possible after clinical human trials to be done in heterogeneous groups across country. Completeness of clinical trials can clear effectiveness and target specificity of present therapy in symptomatic and asymptomatic patients. Clinical trials will also open the way for large-scale use of this method if it remains successful.

(6) Sixth method for production of long term immunity against corona virus:

Take $10 \mathrm{~g}$ of clove buds and $10 \mathrm{~g}$ of makhana (Euryale ferox; Fox nuts) burn, charred them by putting them on hot iron base. Similarly, char $10 \mathrm{~g}$ of dry coconut to ashes (bhasma) by same method. Mix them and make fine powder. Take $1 \mathrm{~g}$ of white alum and warm it on the same hot iron base to remove of its water, it will lose its crystalline structure and become amorphous, take it to make powder and finally mix with previously made charred powder. For using it take $20 \mathrm{~g}$ of honey and
$0.5 \mathrm{~g}$ of this mixture, mix it well and use orally through mouth.

\section{Discussion}

There are series of essential oils which have been tested against various disease pathogens. In the past numerous in vitro studies have clarified the mechanisms through which certain essential oils and their chemical constituents block influenza activity. These essential oils could be used to reduce influenza spread, but the next step to develop aromatic therapies for influenza treatment is to conduct in vivo studies. Star anise essential oil contains components trans-anethole, and sesquiterpenes which target HSV-1 virus replication in vitro plaque reduction assay at a very low dose (Astani et al., 2011). Strong virucidal activity of Melaleuca armillaris essential oil has been reported by Schnitzler et al. (2001). Tea tree (Melaleuca alternifolia) essential oil acts very fast and eliminate airborne influenza droplets within 15 minutes (Usachev et al., 2013; Carson et al., 2006)). Similarly peppermint oil showed strong virucidal action on the enveloped viruses mainly herpes simplex virus type 1 and type 2 in vitro (Schuhmacher, et al., 2003). Similar activity is also reported for oregano and clove against Herpes simplex virus - type 1 (Siddiqui et al., 1996).

Plant terpenoids and lignoids showed potent antiviral activities against severe acute respiratory syndrome coronavirus (Wen et al., 2007). Similarly, sesquiterpene coumarins inhibit cytomegalovirus (Hayashi et al., 1996) while eugenol, a phenyl propane inactivated HSV (Della Porta et al., 1998). Isoborneol, a monoterpene and a component found in several plant essential oils showed virucidal 
Table 2: Nav-deep inhaling method used in thermal aroma-carbon infused therapy

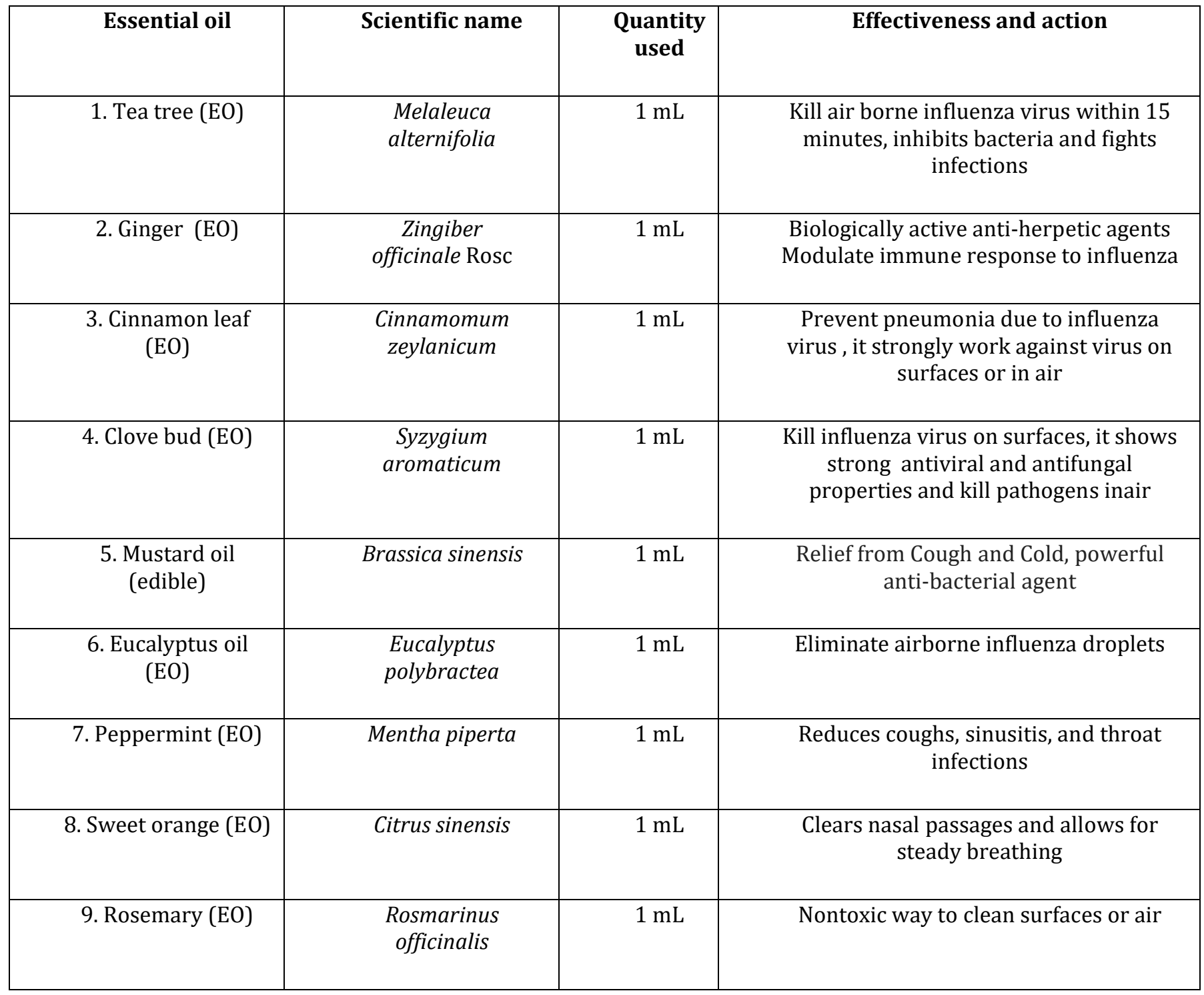

- Blending of essential oils components will take place in air; aromatic clouds can finish the corona virus in air as well as on surfaces. $1 \mathrm{ml}$ quantity of each essential oil is much enough for three hours, clinical operators/ pharmacists and naturopaths can treat uninfected persons for nine minutes, influenza virus patients for 15-20 minutes.

- Separate therapy rooms should be used for infected and uninfected persons.

- Home users can use single bench method for thermal aroma therapy.

- Before using aroma therapy every person must clean nasal passageways with hot water, wash their hands with sanitizer.

- Do not use mask during inhalation of aroma used in present therapy.

- Both effectiveness and output will depend on diffusion and inhalation capacity of person.

- Following each treatment, the room should be aired out by opening a window to allow residual essential oils to leave, and to get fresh air into the room.

activity against HSV-1 and inhibit glycosylation of viral proteins (Armaka et al., 1999), and neutralize action of severe acute respiratory syndrome coronavirus (Wen et al., 2007) and rhinovirus (Rollinger et al., 2008). Similar effect against respiratory bacteria and 
viruses were found in eucalyptus essential oil (Cermelli et al., 2008). Eucalyptus globules and Cinnamomum zeylanicum essential oils also showed antiviral activity (Astani et al., 2010; Vimalanathan and Hudson, 2014). Essential oil components are lipophilic in nature, and can pass through the cell wall and cytoplasmic membrane. They disrupt membrane structure mainly its components polysaccharides, fatty acid and phospholipid layers make it permeable (Bakkali et al., 2008), Various blends of certain essential oils such as Cinnamomum zeylanicum, Daucus carota, Syzygium aromaticum, Origanum vulgare were effective against $\mathrm{H} 1 \mathrm{~N} 1$ and HSV1 viruses (Wu et al., 2010)..

Essential oil components such as terpenes and terpenoids (1,8-cineole carvacrol) and aromatic compounds (cinnamaldehyde and eugenol) can effectively target influenza virus mainly virus replication. Eugenol inhibit Ebola virus in vitro (Lane et al., 2019). Volatile oil of schizonepetae herba and its essential components were found effective against influenza virus (He et al., 2013). These volatile oils attenuate influenza virus (Wu et al., 2010). Even homemade nasal decongestants were also found effective (Sinclair, 1996). Steam distillate from plant Houttuynia cordata also showed virucidal effects against HSV-1, influenza virus and HIV virus (Hayashi et al., 1995). Hence, composite therapy based on herbal preparations that could inhibit virus replication in upper respiratory tract and reduce lung inflammation, lung damage, and pneumonia are also being searched. Herbal preparations for topical or an aerial nasal treatment are highly desirable (Saller et al., 2001). Hopefully, all such answers are possible only after in vivo results. These outcomes will redirect for making necessary improvements in methods and formulations for increasing their target specificity for successful human treatment.

Action of thermal waves and carbon particles on corona virus:

Thermal waves released from mustard oil lamp after burning will increase the ambient temperature of aroma cabin more than 40-42 $C$ set in small room. This thermal heat can denature the virus. Mustard oil (edible oil) burning will generate nano-phase carbon in this open air conventional method. Inhalation of these nano-particles with aromatic essential oil components will prove highly protective against corona virus. In this method thermal heat, carbon colloids and volatile chemicals will work together that may deactivate and neutralize Covid-19 in air during treatment period. Particles intact in nature, will competitively bind with volatile aired aromatic compounds which remain preabsorbed in the air passageway and bronchial tissue cells. It is possible that patient may feel some inflammation during this innate protection activity. But it is true that organic carbon inhaled by patient during treatment period will fall within physiological limits and its effects are restorable.

It is also clear from research studies that nano-scale carbon used for drugencapsulation (DECON) enhance drug delivery and its transport to target organs (Tejabhiram Yadavalli et al., 2019). Both Carbon Dots and carbon nano-particles (Xiuli et al., 2017) were used for combating emerging viral infection (Kerry et al., 2019). The strong evidence in favor of use of organic carbon generated from mustard oil lamp is that traditionally Indians used these earthen "diyas" or lamps for thousands of year without any reported case 
of carbon toxicity. Here I am not denying the fact that carbon particles inhaled by the person might show partial toxicity, but it is also very clear that organic carbon released within 15-20 minutes of exposure or treatment period falls within physiological limits. In the past these mustard oil lamps were lighten throughout night without any adverse effect on users.

A similar approach could be used against corona virus; however, in present method carbon nano-particles generated by burning of mustard oil in open air raise the ambient room temperature 40-42C. Thermal heat waves may swap in RNA particles and denature it. This de-annealed virus RNA will trap in carbon colloids mixed with volatile chemical constituents released from 8 different essential oils in hot air above lamp flame. These all eight essentials are good source of volatile ant-viral compounds and are well tested against different human flu viruses in vitro in various plaque reduction assays, where they loss their replication power. Obviously, naturally typical particle sizes of black carbon particles range from around 8 nanometers to 100 nanometers. Its individual surface area may load essential oil components floating in air. There is much possibility that thermally denatured corona virus bound to nano-carbon colloids with anti-virus compounds inhaled by the patient. Organic carbon colloids will disallow virus attachment on ciliated epithelium. Thus, this mixed method will lower down the virus load in patient lungs. Further, air convection currents move in hot air, increase the ambient room temperature up to $40-45 \mathrm{C}$ that will cause denaturation of virus in air and in upper respiratory tract. Further, rapidly inhaled carbon colloids adhere on bronchial epithelium will trap corona virus. In addition, aromatic constituents will double this virus deactivation due to repeated hot air breathing.

This open air fusion or blending of numerous volatile constituents and organic carbon particles may heavily target corona virus, it will act as a thermal-aroma jacket due to Tyndall effect. This will clear the air passageways after 10-15 repeated breathing in a room. Thus hot air and aroma chemicals can neutralize virus in lungs post inhalation, thus it will reduce virus load. Further, passive diffusion of active ingredients present in herbal syrup will act as a composite drug to protect the gastrointestinal tract, liver and kidney from virus infiltration by using another treatment method no. 6 .

Inhaled hot air and clouds of volatile infused aroma will clear the air passage, sinuses and stop nasal flow after an inhalation for 15-20 minutes in aired room as it is advised in the Figures 2, 3, 4 and 5. Because organic carbon has no functional group it will remain unidentifiable to virus. Colloidal carbon will trap the flu virus (coronavirus) inside it, and its spike protein could not bind to ACE-2 on host cell surface from where virus enters inside cilliary epithelium found in gut (Fig. 6). Coronavirus binds to this receptor 1000 times with higher affinity than animal host cell surface.

Inhalation of essential oil will allow spreading of lung surface area due to relaxation of diaphragm musculature. At 40$45 \mathrm{C}$ temperature air becomes lighter and 


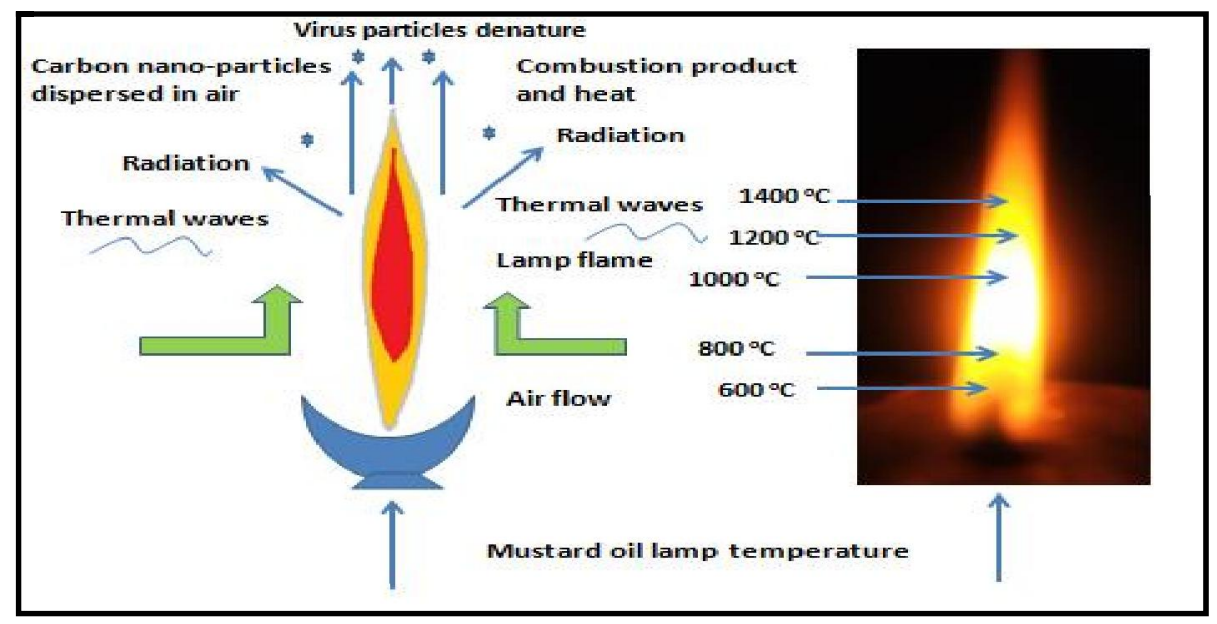

Fig. 4: Mustard oil lamp flame temperature, radiation and thermal waves transmitted in nearby zone and formation of combustion product(s).

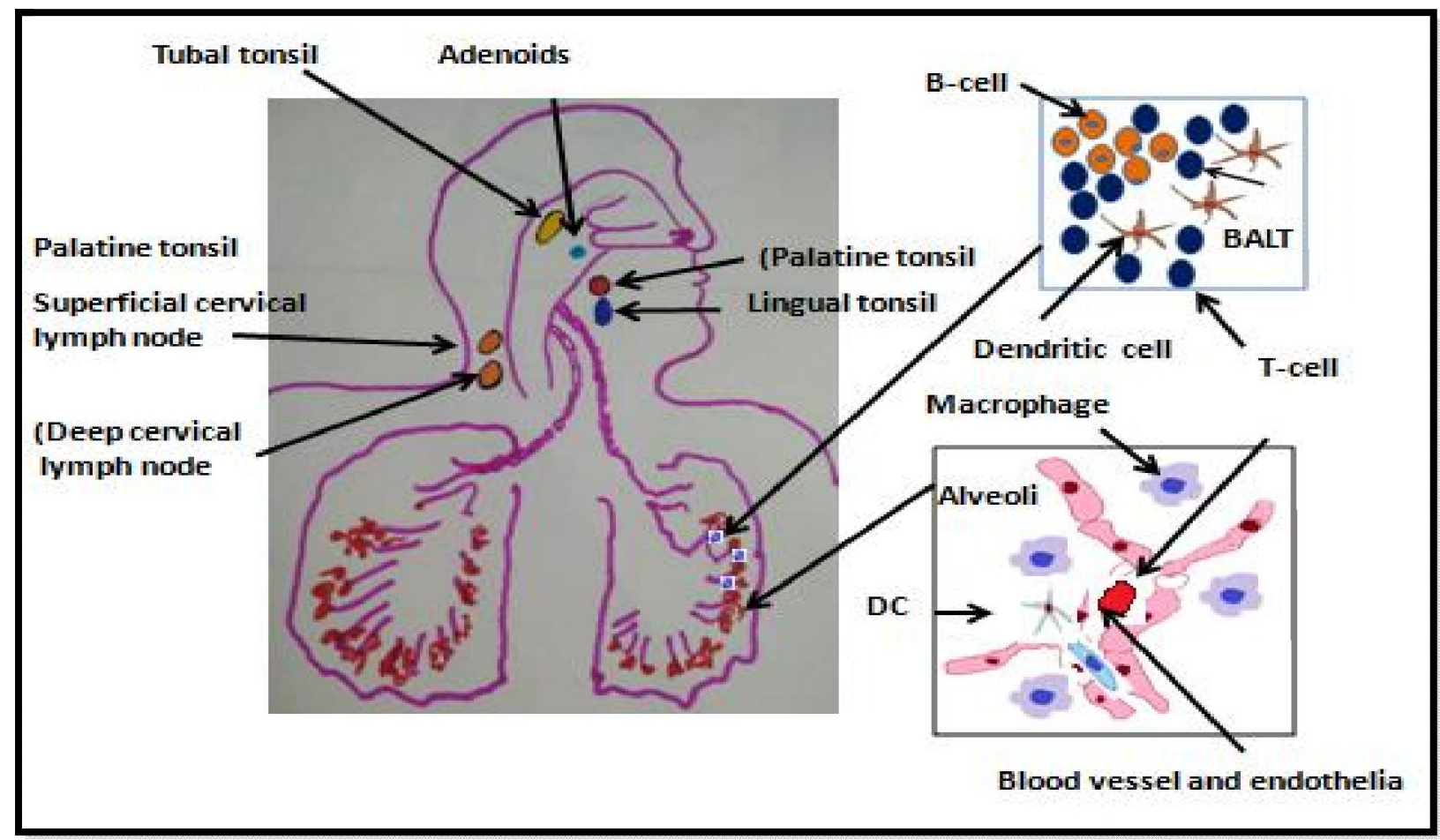

Fig. 5: Bronchus associated mucosal lymphoid tissue mustard oil exhumed with high energy thermal waves, volatile aromatic components of essential oils evaporated and colloidal organic carbon particles as combustion product. Person sitting in thermal aroma zone will inhale more tidal air in a rapid flow due to effect of heat or thermal energy on diaphragm, sternum musculature and lung alveolar tissue. It will check formation of thick dry cough spot in bronchus and assist in clearance of air passageways and upper respiratory tract and lungs. It will also assist protect epithelial cells from virus attack and cud down release of fluid from bronchus tissue and cytokine burst. 


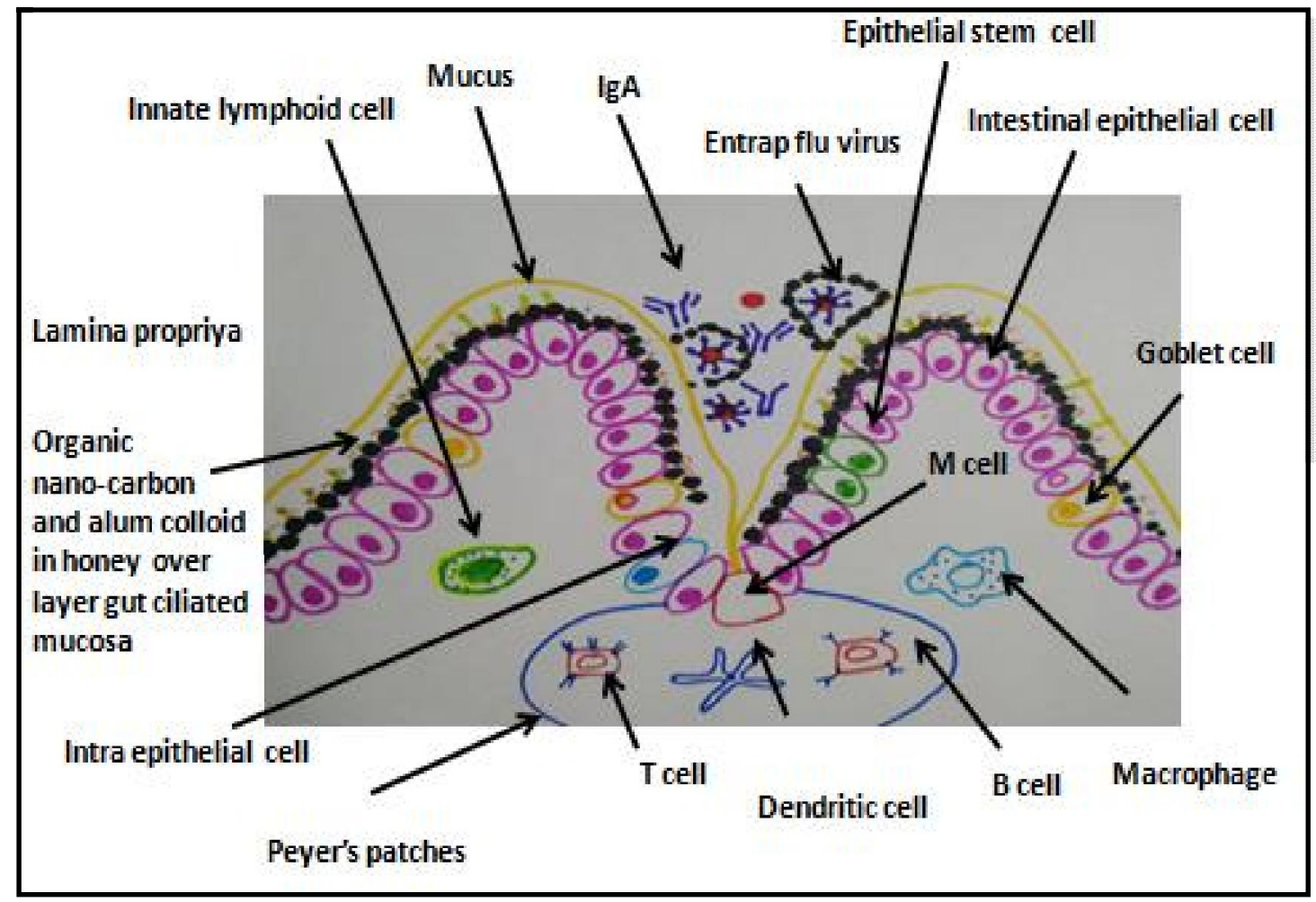

Fig. 6: Mucus associated mucosal lymphoid tissue and its associating cells and structures. Use of "bhasma" having carbonated ingredients mixed in honey and dehydrated alum will protect ciliated epithelial cells from virus attack. Here use of colloidal carbon will trap corona virus and prohibit binding of spike protein with ACE 2 receptor. It will delay the virus entry and replication inside human host.

patient or a normal un-infected person will inhale more air volume. Consequently, it will increase the tidal volume or inspired air volume which is inhaled voluntarily in each normal breath i.e. $500 \mathrm{ml}$. Reason behind increase in air volume is feeling releasing of congestion and increase in blood and activation of hypothalamus, medulla and pons. Of this inhaled air each one of us use $350 \mathrm{ml}$ of it in each breath. Normally, we breathe 12 times in a minute, and inspire $4200 \mathrm{ml}$ of air in one minute. This much volume of air reaches into lungs bronchial tissue, it mixes with the functional residual air volume of alveoli. This much amount of air participates in gaseous exchange, it brings about $69 \mathrm{ml}$ of $\mathrm{O}_{2}$, when expired air comes out, it takes back about $48 \mathrm{ml}$ of $\mathrm{O}_{2}$. Thus, with each breath 21 ml of $\mathrm{O}_{2}$ becomes available to pulmonary blood for absorption and oxygenation from alveolar air. More often, our normal intake of $\mathrm{O}_{2}$ amounts to about $250 \mathrm{ml}$ per minute. Persons who remain in air conditioners they inhale more oxygen per minute or their lungs adopt a forced high inhaled air volume that is too risky (Freed and Davis 1999). However, their ciliated epithelium in lungs get irritated and inflamed (McLane et al, 2000; D'Amato et al, 2018). During influenza attack their air passageways get choked with hard phlegm and they need high oxygen supply, hence, they need ventilator, and cannot resist high pressure of air generated in ventilator (Koskela, 2007). Normally we are accustomed of quite breathing which is also known as abdominal breathing, by effect we can 
voluntarily take a deep forced or heavy breathing. But patients who were having bailey fat they apply more force on diaphragm for breathing due to shortening of thoracic cavity and their expiration is severely affected, hence they need ventilator because of high expiration reserve air volume. In a state of smaller supply of inspiration air and low diffusion of oxygen in influenza attack they generate sepsis and bronchial tissue failure due to cytokine burst and filling of air space by heavy fluid in lungs. In such a condition within $6 \mathrm{hrs}$ of air passage obstruction patient died due to sepsis shock syndrome. This is the main reason that $80 \%$ of mortality was seen in out bailey and overweight patients in last two months in different countries. In 20 minute treatment with thermal aroma-carbon therapy a patient will get $9 \times 20 \times 350 \mathrm{ml}$ of air equivalent to $63000 \mathrm{ml}$ of air (in 20 minutes), of that is much enough for absorption of normal amount of oxygen after alveolar diffusion. Inhalation of this much air volume in repeated breathing causes clearance of nasal air passage, trachea and lungs. About $150 \mathrm{ml}$ of inspired air or expired air in each breath is retained in the respiratory passageways. This air never participates in gaseous exchange but it is required for humidification of air passages. In normal quite breathing the diaphragm plays the primary (75\%) role and other muscles that move the sternum and plays a necessary $(25 \%)$ role in breathing movements. For large scale use follow arrangement given in Figure 2 .

Further, use of syrup and organic bhasma alum mixed with honey save from sepsis due to obstruction of virus entry or infiltration in liver and kidney of patients. These will provide longevity to patient beyond 14 days until and unless humoral immune response is being made in his/her body. If present strategy becomes successful then the use of ventilator will reduce and only chronic corona patient will need this facility. For an invisible enemy a drug whose structure remains untraceable /unrecognizable to virus will work perfectly. Radiation/high energy light spectrum, thermal waves, aired aromatic antivirus chemicals coated or fused with carbon nano-particles can more efficiently hit corona virus in air, finally denature it. Similar happening may also occur in air. RNA particle has a nature like a fission reaction, as neutrons are emitted from atom nucleus in a chain reaction, however, to finish virus particle or for its neutralization in air, fusion technology will work. Colloidal carbon infusion with virus particles may result in loss of RNA activity.

Alum facilitates effective and long-lasting protective immunity in hosts, mainly by inducing antibody responses. Alum is also used for precipitation of protein antigens and can assist in purity testing. An admixture of white alum induces immune response against the microbial pathogens. A regulated amount of alum i.e. $1 \mathrm{~g}$ of white alum, $5 \mathrm{~g}$ of clove buds (Charred powder) and $5 \mathrm{~g}$ of makhana (Charred powder) admixture in $60 \mathrm{ml}$ of fresh honey is sufficient dose for three days for a single person to enhance immunity against corona virus. Alum starts its action as soon it reaches into the gastrointestinal tract and stop virus adhesion on ciliated mucosa. It also kill virus in biological fluids, enhance phagocytosis and restore innate immune or germ line defense. White alum also mediates transport of antigen through multiple steps from antigen uptake to final B-cell antibody 
production, thus it may boost up humoral immune response and induce cell mediated immunity in patients body.

In present method alum is used for increasing the target specificity of synergistic action of therapeutic molecules by delivering at target areas where corona virus shows its proliferation. Alum increases adjunvanticity (Mirjam Kool et al., 2012) that was proved by few of licensed vaccines such as diphtheriapertusis-tetanus (DPT), diphtheria-tetanus (DT) and also combined with Haemophilus influenza B, inactivated polio vaccine, Hepatitis B virus, and hepatitis A virus vaccines ((Lindblad, 2004; Harm HogenEsch et al., 2018). Use of alum assists body in generation of $\mathrm{T}$ helper responses and can stop cytokine release and burst in lungs (Brewer et al., 1996). Alum causes surface killing of viruses within and outside host (Yasir Waheed et al., 2011). Use of alum increases phagocyte activation, caspase-1 conversion and IL-1 $\beta$ production in antigen-presenting cells. It form inflammasome/ activated caspase- 1 activity (Davis et al., 2011) that mediate several forms of cell death and does conversion of immature precursors of inflammatory cytokines to their active forms i. e interleukin- $1 \beta$ (IL-1 $\beta$ ), IL-18 and IL-33 (Sutterwala et al., 2014). Productions of these cytokines enhance $\mathrm{Ca}^{2+}$ influx, $\mathrm{K}^{+}$efflux and generate mitochondria-originated reactive oxygen species (Li et al., 2007).

Acid induced inactivation of herpes simplex virus type 1 (HSV-1) and type 2 (HSV2), the influenza A virus (IAV) and the poliovirus was done by using various electrolytes i.e., phosphate, $\mathrm{NaCl}$, glutamate, aspartate, pyrrolidone carboxylate, citrate, malate and acetate upon their incubation at $30 \mathrm{C}$ for $5 \mathrm{~min}$ (Nishide et al., 2011). Similarly arginine and $\mathrm{NaCl}$ inactivate i.e. herpes simplex virus type 1 (HSV-1) and influenza virus type at neutral $\mathrm{pH}$ conjunction with elevated temperature between 40-50 C. Both arginine and $\mathrm{NaCl}$ (1.2M) decrease the inactivation temperature required for virus inactivation. A significant over $90 \%$ virus inactivation of HSV-1 was occurred above 50 C (Utsunomiya et al., 2009)

\section{Caution:}

It is a well known fact that ocean is a large natural habitat of thermophilic viruses which are found in ocean basement (Nigro et al., 2017). So far studies have been done on 6 viruses i.e. infectious pancreatic necrosis virus (IPNV), infectious hematopoetic necrosis virus (IHNV), infectious salmond anemia virus (ISAV), nervous necrosis virus (NNV), epizootic hematopoietic necrosis virus (EHNV), infectious spleen and kidney virus (ISKNV). Koi herpes virus (KHV) have been reported in shrimps. These viruses cause serious infection both in marine and fresh water shrimps and cause mass mortality in them within few days (Lightner, 2008). Besides, these viruses other lethal viral diseases also affect shrimp population (Crustacean diseases, 2001). Among them nidovirus is a gill-associated virus of Penaeus monodon prawns (Cowley et $a l, 2000,2004$; Walker, 2002). Even it is very clear about shrimps, no virus free shrimp populations found in the wild, and individual shrimp often carry multiple viruses (Madhavi et al., 2002; Flegel et al., 2004; Natividad et al., 2006; Umesha et al., 2008).

Present emerging corona virus is also showing much similarity with gut associating 
hepatopancreatitis respiratory virus found in shrimps. Because of its very high oxygen requirement, high disease transmission, high morbidity and mortality rate virus imposed a real danger (Dennis, 2020). In yellow shrimps this virus grows in gills, generate sepsis in lungs, liver, pancreas, kidney and mucosal lining of gut. It causes heavy tissue necrosis in vital organs, slow down tissue respiration and imposes high morbidity due to failure of dense making molecules which participate in various immune defense pathways (Peter and James, 2014). Shrimps lack the key components of adaptive and innate immune response mechanisms (i.e., antibodies, lymphocytes, cytokines, interferon) and, although Toll-like receptors have been identified. They also lack mechanisms to make anti-viral immunity (Labreuche et al., 2007; Yang et al., 2007). Though, virus infections occur commonly in apparently healthy populations of wild fish and shrimp and, although disease outbreaks may occasionally occur and their natural cycle of transmission occur by water itself (Ward and Lafferty 2004).

As general nature of communicable viruses they show infection in particular confined geographical area. They take year's time in becoming from epidemic to pandemic. There are two hard facts about corona virus it needs 10 times high oxygen supply and shows 1000 times' high affinity to bind with ACE-2 enzyme in human host. Naturally both characters were never observed in terrestrial flu viruses. High oxygen requirement of virus shows its aquatic nature and high replication in a buffered $\mathrm{pH}$ much similar to oceanic water, but its high infectivity and mortality is because of artificial mutations. More possibly corona virus is a WMD as it has shown its presence in more than 207 nations of the world only in three months. This is first wave of virus; possible a second heavy wave with mild to high pathogenicity will come in future but it is still unpredictable now.

Sanguivorous bats found in Wuhan province of China have this virus. Pangolins are also other host of this virus and showed 96\% homology, but their transmission routes is also not very clear. The easiest transmission could be possibly by eating raw seafood mainly cultivated marine shrimps. There is a possibility that virus may also host in other animal whose transmission route is not known. Frugivorous bats are also found in most of South-East Asian countries, but no such corona virus infection has been reported in them.

\section{Diet of patients:}

Because it is herbal method hence patent should provide roasted channa, bajra, maize or wheat dalia. Jau chapatti contains ferritin a protein that can fight against microbial pathogens. Use of ice cream, cold drinks, smoke, tobacco, alcohol, chewing gums is strictly prohibited. Do not keep patient in AC room, disinfect freezes, freezers, and other appliances. Always bear mask and use hot water after cooling it to lukewarm during clinical treatment. Avoid eating junk food and non-vegetarian items. Wash cloths with soap and air dry cloths.

\section{Precautions:}

RT-PCR based valid confirmatory test must be performed for proper screening of Covid-19 positive patients before using this method. However, essential oils should be used with care, they shouldn't be used internally and 
avoid their ingesting. Essential oils may not be safe to use during pregnancy. For example, there may be a risk that the active ingredients will cross the placenta and affect the fetus. For inhalation therapy, float the essential oils in hot water and inhale the vapors, or use a room diffuser. Inhaling eucalyptus may help ease congestion. It is never safe to consume essential oils, and children should not use them in any way. Take vitamin C, B-complex mainly $B_{3}$ and vitamin $D$ by sitting in sunshine for good health. Do aerobics or yoga exercise and take balanced diet for living a healthy life.

\section{Conclusion}

Present therapy is not based on presumptions but designed by studying well established scientific facts and outcomes from various researches done on control of microbes round the globe. Both therapeutic methods and ingredients are natural and present least side effects if use safely under strict direction of clinicians. Though, whole therapy found workable in limited trials/ experiments. Before use people should pass through preliminary testing, use only when found it suitable with no adverse effect on body. In a condition of negative effect they should not use this method. In such cases clinical advice will be foremost and final. Present health care costs are high, use of more expensive drugs will creating greater burden on government and other health systems. Today, there is an utmost requirement for the development of novel method for successfully combining against most deadly virus Covid-19. A cheapest and effective method may not only protect human health but also protect our economy. In the last, I would like to say to scientists, clinicians, pharmacists, technologists, pharmaceutical companies, research laboratories, institutes and world leadership kindly try and use all possible methods i.e. vaccine, plasma therapy, antiviral drugs, ACE-2 analogues, SCPs, protease and polymerase inhibitors, natural products, Ayurvedic preparations, homeopathic, alternative and complementary medicine and physical devices to fight strongly against this pandemic. Preparation of an appropriate vaccine against this virus will take months time; hence, all conventional methods should try to control this deadly disease. A strong weapon that can more efficiently cut down virus load, stop its replication and entangle the virus by making non-adherence and inhibit binding of spike protein with ACE-2 receptor of human host will be most successful.

\section{Conflict of interest}

Author has no conflict of interest to anyone.

\section{Acknowledgement}

This therapy is only after great kindness and blessings of great Mahayogi, Baba Guru Gorakh Nath Ji Maharaj. I personally inspired by his holy phrase Alakh Niranjan. I pray to Supreme Divine power and urge kindly forgive people and provide them safety from present pandemic.

\section{References}

Armaka M, Papanikolaou E, Sivropoulou A and Arsenakis M. (1999) Antiviral properties of isoborneol, a potent inhibitor of herpes simplex virus type 1. Antiviral Research 43: 79-92.

Astani A, Jurgen R. and Paul S. (2011) Screening for antiviral activities of isolated compounds from essential oils. Evidence-Based Complementary Alternative Medicine (Article ID 253643) doi:10.1093/ecam/nep187.

Bakkali F, Averbeck S, Averbeck D and Idaomar M. (2008) Biological effects of essential oils--a review. Food Chem. Toxicol. 46: 446-475. 
Benencia F and Courrges MC. (2000) In vitro and in vivo activity of eugenol on human herpes virus. Phytotherapy Research 14: 495-500.

Brewer JM, Conacher M, Satoskar A, Bluethmann H and Alexander J. (1996) In interleukin-4-deficient mice, alum not only generates $\mathrm{T}$ helper 1 responses equivalent to Freund's complete adjuvant, but continues to induce T helper 2 cytokine production. Eur. J. Immunol. 26: 2062-2066.

Brocht A, Guilbot A, Haddioui L and Roques C. (2017) Antimicrobial, anti-fungal, and anti-viral effects of three essential oil blends. MicrobiologyOpen: 6: e459. DOI: $10.1002 / \mathrm{mbo3.459.}$

Camero M, Lanave G, Catella C, Capozza P, Gentile A, Fracchiolla G, Britti D, Martella V, Buonavoglia C, Tempesta M. (2019) Virucidal activity of ginger essential oil against caprine alphaherpesvirus-1. Vet. Microbiol. 230:150-155.

Carson CF, Hammer KA and Riley TV. (2006) Melaleuca alternifolia (tea tree) oil: A review of antimicrobial and other medicinal properties, Clinical Microbiology Reviews 19: 50-62.

Cermelli C, Fabio A, Fabio G and Quaglio P. (2008) Effect of eucalyptus essential oil on respiratory bacteria and viruses. Current Microbiology 56: 89-92.

Cowley JA, Dimmock CM, Spann KM and Walker PJ. (2000) Gill-associated virus of Penaeus monodon prawns: an invertebrate virus with ORF1a and ORF1b genes related to arteri- and coronaviruses. J. Gen. Virol. 81:1473-1484.

Cowley JA, Cadogan LC, Spann KM, Sittidilokratna N and Walker PJ. (2004) The gene encoding the nucleocapsid protein of gill-associated nidovirus of Penaeus monodon prawns is located upstream of the glycoprotein gene. J. Virol. 78: 8935-8941. doi:10.1128/JVI.78.16.8935-8941.2004.

D’Amato Maria, Antonio Molino, Giovanna Calabrese, Lorenzo Cecchi, Isabella Annesi Maesano and D'Amato G. (2018) The impact of cold on the respiratory tract and its consequences to respiratory health. Clin. Transl. Allergy 8: 20.

Davis BK, Wen $H$ and Ting JP. (2011) The inflammasome NLRs in immunity, inflammation, and associated diseases. Annu. Rev. Immunol. 29:707-735

De Flora S and Badolati G. (1973) Thermal inactivation of untreated and $\gamma$-irradiated A2-Aichi-2-68 influenza virus. J. Gen. Virol. 20: 261-265.

De Logu A, Loy G, Pellerano ML, Bonsignore L and Schivo ML. (2000) Inactivation of HSV-1 and HSV-2 and prevention of cell-to-cell virus spread by
Santolina insularis essential oil. Antiviral Res. $48: 177-185$.

Della Porta G, Taddeo R, D'Urso E and Reverchon E. (1998) Isolation of clove bud and star anise essential oil by supercritical $\mathrm{CO} 2$ extraction. Lebensmittel-Wissenschaft und-Technol. 31: 454460.

Dennis N. (2020) Novel human virus? Pneumonia cases linked to seafood market in China stir concern. https:// ww.sciencemag.org/news/2020/01/novelhuman-virus-pneumonia-cases-linked-seafoodmarket-china-stir-concern\#

Epand Richard M and Epand Raquel F. (2002) Thermal denaturation of influenza virus and its relationship to membrane fusion Biochem. J. 365: 841-848.

Estola T. (1970) Coronaviruses, a new group of animal RNA Viruses. Avian Diseases 14 : 330-336.

Flegel TW, Nielsen ., Thamavit V, Kongtim S and Pasharawipas T. (2004) Presence of multiple viruses in non-diseases cultivated shrimp at harvest. Aquaculture 240: 55-68.

Freed AN and Davis MS. (1999) Hyperventilation with dry air increases airway surface fluid osmolality in canine peripheral airways. Am. J. Respir. Crit. Care Med. 159:1101-1107.

Harm HogenEsch, Derek T O'Hagan and Christopher BF. (2018) Optimizing the utilization of aluminum adjuvants in vaccines: you might just get what you want. npj Vaccines 3: 51. https://doi.org/ 10.1038/s41541-018-0089-x

Hayashi K, Kamiya M and Hayashi T. (1995) Virucidal effects of the steam distillate from Houttuynia cordata and its components on HSV1, influenza virus, and HIV. Planta Med. 61:237- 41.

Hayashi K, Hayashi T, Ujita K and Takaishi Y. (1996) Characterization of antiviral activity of a sesquiterpene, triptofordin C2. J. Antimicrobial Chemotherapy 37): 759-768.

He T, Tang Q Zeng N, Gou L, Liu JW, Yang J, Yu L, Wang Z and Gong XP. (2013) Study on effect and mechanism of volatile oil of schizonepetae herba and its essential componentsagainst influenza virus. Z Zhong Yao Za Zhi. 38:1772-1777.

Hem SL and HogenEsch H. (2007) Aluminumcontaining adjuvants: properties, formulation, and use. In: Vaccine Adjuvants and Delivery Systems (ed. Singh M) 81-114, John Wiley and Sons, Inc., Hoboken, N.

Kerry Rout G, Santosh M, Yisehak T Redda, Sabuj Sahoo, Jayanta Kumar Patra and Sanatan M. (2019) Nanobased approach to combat emerging viral (NIPAH 
virus) infection. Nanomedicine: Nanotechnology Biology Medicine 18:196-220.

Koskela HO. (2007) Cold air provoked respiratory symptoms: the mechanism and management. Int. J. Circumpolar Health. 66: 91-100.

Labreuche Y, O'Leary NA, de la Vega E, Veloso A, Gross PS, Chapman R.W, Browdy CL and Warr GW. (2009) Lack of evidence for Litopenaeus vannamei Toll receptor (IToll) involvement in activation of sequence-independent antiviral immunity in shrimp. Dev. Comp. Immunol. 33: 806-810.

Lane T, Anantpadma M, Freundlich JS, Davey RA, Madrid PB and Ekins S. (2019) The natural product eugenol is an inhibitor of the Ebola virus in vitro. Pharm. Res. 36:104. doi: 10.1007/s11095-019-2629-0.

Li H, Nookala S and Re F. (2007) Aluminum hydroxide adjuvants activate caspase- 1 and inducelL-1 beta and IL-18 release. J. Immunol. 178: 5271-5276.

Lightner DV. (2008) The Penaeid shrimp viruses TSV, IHHNV, WSSV, and YHV: Current status in the Americas, available diagnostic methods, and management strategies. J. Appl. Aquacult. 9: 27-52.

Lindblad EB. (2004) Aluminium compounds for use in vaccines. Immunol. Cell Biol. 82: 497-505.

Madhavi R, Janakiram P, Jayasree L and Murthy PSN. (2002) Occurrence of concurrent infections with multiple viruses in Penaeus monodon from culture ponds of north coastal Andhra Pradesh. Curr. Sci. 82: $1397-1400$.

McLane ML, Nelson JA, Lenner KA, Hejal R, Kotaru C, Skowronski M, Coreno A, Lane E and McFadden ER Jr. (2000) Integrated response of the upper and lower respiratory tract of asthmatic subjects to frigid air. J. Appl. Physiol. 88:1043-1050.

Mirjam Kool, Kaat F and Bart N L. (2012). Alum adjuvant: some of the tricks of the oldest adjuvant. J. Medical Microbiol. 61: 927-934.

Natividad KDT, Migo MVP, Albaladejo JD, Magbanua JPV, Nomura N and Matsumura M. (2006) Simultaneous PCR detection of two shrimp viruses (WSSV and MBV) in post-larvae of Penaeus monodon in the Philippines. Aquaculture 257: 142-149.

Nigro OD, Jungbluth SP, Lin HT, Hsieh CC, Miranda JA, Schvarcz CR, Rappé MS and Steward GF. (2017) Viruses in the oceanic basement. mBio. 8: pii: e02129-16. doi: 10.1128/mBio.02129-16.

Nishide M, Tsujimoto K, Uozaki M, Ikeda K, Yamasaki H, Koyama AH and Arakawa T. (2011) Effects of electrolytes on virus inactivation by acidic solutions. Int. J. Mol. Med. 27: 803-809.
Peter JW, and James RW. (2010) Emerging viral diseases of fish and shrimp. Vet. Res. 41: 51.

Piątkowska E and Rusiecka-Ziółkowska J. (2016) Influence of essential oils on infectious agents. Adv. Clin. Exp. Med. 25: 989-995.

Rice ESA and Doty P. (1957) The thermal denaturation of deoxyribonucleic acids. J. Am. Chem. Soc. 79: 3937-3947.

Rollinger JM, Theodora MS Daniela S, Johannes K, Kathrin A, Ernst PE, Thierry L, Hermann S, Peter W and Michaela S. (2008) Structure based virtual screening for the discovery of natural inhibitors for human rhinovirus coat protein. J. Medicinal Chem. 51: 842-851.

Rosato A, Carocci A, Catalano A, Clodoveo ML, Franchini C, Corbo F, Carbonara GG, Carrieri A and Fracchiolla G. (2018) Elucidation of the synergistic action of Mentha piperita essential oil with common antimicrobials. PLoS One 13: e0200902. DOI: 10.1371/journal.pone.0200902

Ruigrok RW, Martin SR, Wharton SA, Skehel JJ, Bayley PM and Wiley DC. (1986) Conformational changes in the hemagglutinin of influenza virus which accompany heat-induced fusion of virus with liposomes. Virology 155: 484-497.

Saller R, Buechi S, Meyrat R and Schmidhauser C. (2001) Combined herbal preparation for topical treatment of herpes labialis. Forsch Komplementärmed Klass Naturheilkd 8: 373-382. https://doi.org/10.1159/000057255.

Schnitzler P, Schon K and Reichling J. (2001) Antiviral activity of Australian tea tree oil and eucalyptus oil against herpes simplex virus in cell culture. Pharmazie 56: 343-347.

Scholtissek C. (1985) Stability of infectious influenza A viruses at low $\mathrm{pH}$ and at elevated temperature. Vaccine 3: 215-218.

Schuhmacher A, Reichling J and Schnitzler P. (2003) Virucidal effect of peppermint oil on the enveloped viruses herpes simplex virus type 1 and type 2 in vitro. Phytomed. 10: 504-510.

Siddiqui Y M, Ettayebi M, Haddad AM and AlAhdal MN. (1996) Effect of essential oils on the enveloped viruses: antiviral activity of oregano and clove oils on herpes simplex virus type 1 and Newcastle disease virus. Medical Science Res. 24: 185-186.

Sinclair A. (1996) Remedies for common family ailments: 10. Nasal decongestants. Prof Care Mother Child 6: 9-11. 
Sutterwala FS, Haasken S and Cassel SL. (2014) Mechanism of NLRP3 inflammasome activation. Ann. NY Acad Sci. 1319: 82-95.

Tejabhiram Yadavalli, Joshua A, Alex A, Suryawanshi R, Dinesh J, James H, Neel T, Lulia K and Shukla D. (2019), Drug-encapsulated carbon (DECON): A novel platform for enhanced drug delivery. Sci. Adv. 5: eaax0780. DOI: 10.1126/sciadv.aax0780.

Umesha KR, Chakraborty A, Venugopal Nagarajappa M, Karunasagar I and Karunasagar I. (2008) Occurrence of multiple viruses in Penaeus monodon shrimp ponds and their effects on shrimp production. In: Diseases in Asian aquaculture VI. Fish Health Section, Eds. Bondad-Reantaso MG, Mohan CV, Crumlish M and Subrasinghe RP. Asian Fisheries Society, Manila, Philippines, pp. 389-398.

Usachev Evgeny V, Oleg VP, Olga VU and Igor EA. (2013) Antiviral activity of tea tree and eucalyptus oil aerosol and vapour. J. Aerosol Sci. 59: 22-30.

Utsunomiya $H$, Ichinose $M$, Tsujimoto $K$, Katsuyama Y, Yamasaki H, Koyama AH, Ejima D and Arakawa T. (2009) Co-operative thermal inactivation of herpes simplex virus and influenza virus by arginine and NaCl. Int. J. Pharm. 366: 99-102.

Vimalanathan S and James HH. (2014) Anti-influenza virus activity of essential oils and vapors. Am. J. Essential Oils Natural Prod. 2: 47-53.

Vlietinck D, Cos P, Berghe AJV and Maes L. (2006) Antiinfective potential of natural products: how to develop a stronger in vitro 'proof-of-concept'. J. Ethnopharmacol. 106: 290-302.

Walker PJ. (2002) The complete genome sequence of gill-associated virus of Penaeus monodon prawns indicates a gene organisation unique among nidoviruses. Arch Virol. 147:1977-1987.

Wallace JI and Franklin R. (1967) Denaturation and renaturation of viral ribonucleic acid II. Characterization of the products resulting from annealing r17 ribonucleic acid with denatured replicative form or with denatured replicative intermediate. J. Virology 1: 793-803.

Ward JR and Lafferty KD. (2004) The elusive baseline of marine disease: Are diseases in ocean ecosystems increasing? PLOS Biol. 2: 542-547.

Wen CC, Kuo YH and Janetal TJ. (2007) Specific plant terpenoids and lignoids possess potent antiviral activities against severe acute respiratory syndrome coronavirus. J. Med. Chem. 50: 4087-4095.

Wu S, Patel KB, Booth LJ, Metcalf JP, Lin HK and Wu W. (2010) Protective essential oil attenuates influenza virus infection: an in vitro study in MDCK cells. BMC Complement Altern. Med. 10:69. doi: 10.1186/1472-6882-10-69.

Xiuli Dong, Marsha MM, Fan Yang, Ya-Ping Sun and Liju Y. (2017) Carbon dots' antiviral functions against noroviruses. Sci. Rep. 7: 519.

Yang LS, Zhi-XinYin, Ji-XiangLiao, Xian-DeHuang, Chang-JunGuo, Shao-PingWeng, Siu-MingChan, XiaoQiangYu and Jian-GuoH. (2007) A Toll receptor in shrimp, Mol. Immunol. 44:1999-200.

Yasir Waheed, Sher Zaman Safi and Ishtiaq Q. (2011) Role of potash alum in Hepatitis $C$ virus transmission at barber's shop. Virology J. 8: 211. 